\title{
Advanced Test Reactor National Scientific User Facility (ATR NSUF) Monthly Report January 2015
}

Renae Soleberg

January 2015

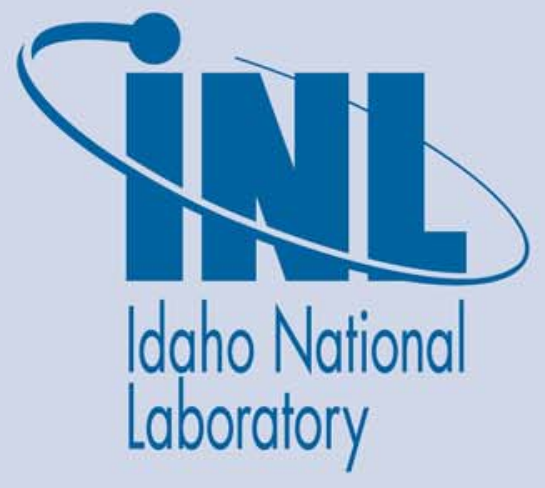

The INL is a U.S. Department of Energy National Laboratory operated by Battelle Energy Alliance 


\title{
Advanced Test Reactor National Scientific User Facility (ATR NSUF) Monthly Report January 2015
}

\author{
Renae Soelberg
}

January 2015

\author{
Idaho National Laboratory \\ Idaho Falls, Idaho 83415
}

http://www.inl.gov

Prepared for the

U.S. Department of Energy

Office of Nuclear Energy

Under DOE Idaho Operations Office

Contract DE-AC07-05ID14517 


\section{Nuclear Science User Facilities (NSUF)}

Formerly: Advanced Test Reactor National Scientific User Facility (ATR NSUF)

Monthly Report

January 2015

\section{Highlights}

- Mike Worley and Shane Johnson visited INL Jan. 22 for an NSUF strategy discussion.

- On January 29, 17 Proposals were received in the winter Rapid Turnaround Experiment (RTE) call. One will be disqualified due to it not fitting into the call guidance. Three national labs and eight universities submitted proposals. Two of the university proposals are from non U.S. universities. We have one from University of Oxford and another from the University of Manchester in the UK. This is the first time we have ever had proposals from universities outside the U.S.

- Of the thirty one pre-applications for NSUF access in the Consolidated Nuclear Innovative Research FOA, thirteen were invited to submit full applications. Three of the uninvited preapplications have expressed intent to submit an uninvited full application. Feasibility studies and cost estimates are in process for all sixteen applications.

\section{Milestones}

- Infrastructure Database Review Committee: The Database Review Panel (DRP) charter has been approved by the Deputy Assistant Secretary for Science and Technology Innovation. The Panel has five members: Brenden Heidrich (NSUF), DOE program office representation (Jason Tokey) and three external members representing the national laboratory complex, academic researchers and industrial/commercial R\&D. All proposed members have accepted membership on the Panel.

\section{Major Accomplishments/Activities}

- Development was initiated for the web portal of the Nuclear Energy Infrastructure Database. The Database Review Panel was formed and commenced work reviewing the structure and usability of the database. The initial NE R\&D gap analysis for FY15 was also started. 
- NSUF Access feasibility studies for the Consolidated Innovative Nuclear Research FOA applications will be completed before Feb. 19.

- In February, Jim Cole will be attending the OECD NEA Expert Group on Innovative Structural Materials meeting in Paris, France.

- Jim Lane and Doug Copsey of Writers Ink are tentatively scheduled to visit PNNL in February to prepare an article for the NSUF annual report.

- University of California-Berkeley Principal Investigator Mehdi Balooch will visit PNNL in February to observe measurements and help finalize plans for completing the desired suite of analyses. His visit is being coordinated to coincide with the visit of Jim Lane and Doug Copsey.

- Rory Kennedy, NSUF staff, and DOE HQ staff will be visiting most of the partner facilities in March and April.

- Jeff Benson and Sarah Robertson will be attending The Minerals, Metals and Materials Society conference in March.

- Jim Cole and Brenden Heidrich will be participating in the NE-4 infrastructure review panels in March.

- Brenden Heidrich will be attending the European Research Reactor Conference in April.

\section{Research Project Highlights}

- Janelle Wharry (Boise State University) completed RTE 14-485 "Correlating mechanical properties with microstructure evolution in irradiated F/M and ODS alloys" at the Center for Advanced Energy Studies (CAES) Microscopy and Characterization Suite (MACS).

- Janelle Wharry (Boise State University) completed RTE 14-486 "Irradiation-induced segregation, phase stability, and microstructure in 8-10 wt\% Cr ODS alloys" at the Center for Advanced Energy Studies (CAES) Microscopy and Characterization Suite (MACS). 